COMPUTING IN MEDICINE 


\section{COMPUTING IN MEDICINE}

Proceedings of a seminar on computing applied to medicine, held at the University of Strathclyde, Glasgow, in August 1981

\section{Edited by}

J. P. PAUL, M. M. JORDAN, M. W. FERGUSON-PELL and B. J. ANDREWS

Editorial Associates

E. M. SMITH and M. K. McColl

Bioengineering Unit

Wolfson Centre

University of Strathclyde 
(c) Bioengineering Unit, University of Strathclyde 1982

Softcover reprint of the hardcover 1st edition 1982 978-0-333-31886-7

All rights reserved. No part of this publication may be reproduced or transmitted, in any form or by any means, without permission

First published 1981 by

Scientific and Medical Division

THE MACMILLAN PRESS

London and Basingstoke

Companies and representatives throughout the world

Typeset in Great Britain by

RDL., 26 Mulgrave Road, Sutton, Surrey

Printed by Unwin Brothers Limited,

The Gresham Press, Old Woking, Surrey

ISBN 978-1-349-06079-5 ISBN 978-1-349-06077-1 (eBook)

DOI 10.1007/978-1-349-06077-1 


\section{PREFACE}

The fourth in the series of Strathclyde Bioengineering Seminars was held in August 1981 and considered the wide and highly topical subject of computing applied to medicine. Seminars in the present series were preceded by two broad-spectrum symposia held in 1964 and 1972. The series has covered the areas of Tissue Viability and its Clinical Applications, Extracorporeal Blood Treatment Systems, and Rehabilitation of the Disabled. These seminars were published by the Macmillan Press under the titles of Bedsore Biomechanics (July 1976), Artificial Organs (July 1977) and Disability (December 1979).

The present volume and the associated seminar mark a milestone both for the series and for bioengineering. Professor R. M. Kenedi, who initiated the series, organised the meetings and edited their proceedings, retired from the University of Strathclyde in 1980 and took up the post of Associate Director (Engineering) in Hong Kong Polytechnic. Prior to his departure from Glasgow, Professor Kenedi initiated the preparation for this meeting and it was with great pleasure that we were able to welcome him back to introduce the Adam Thomson Lecture given by Mr Jack Perkins, and to participate in the seminar and its functions.

Dr Monica M. Jordan, one of the editors of this volume, was a member of the Bioengineering Unit until February 1980, when she took un a post in the National Institute of Medical Research, Mill Hill, London. She has been involved at a high level in the planning and organisation of this meeting, both before and after her translation.

The present seminar, the fourth in the series, was held in August 1981 and related to research and development in applications of computers and microprocessors in the field of medical practice. Special sessions included signal and image analysis, medical statistics, teaching, and modelling of physiological systems. It was attended by 190 registrants from the United Kingdom, Australia, Canada, Denmark, Eire, the Faroe Islands, France, Hong Kong, India, Israel, Italy, Japan, Mexico, Netherlands, Norway, Portugal, Turkey, USA and West Germany.

The details for the sections are given in the contents list and the companies and organisations participating in the scientific and industrial exhibition are identified on page viii. The organisers wish to express their particular appreciation for the support of the industrial exhibitors in being present to show their equipment and in contributing to the finances of the occasion.

Being aware of the financial difficulties facing young people starting in their careers who wished to attend seminars of this type, financial support for the registration of six relevant persons was provided by Messrs Ferranti, Hewlett Packard and IBM, and the organisers of the seminar extend to these companies 
the thanks of the individuals supported. In the financial crises facing universities at this time, it is easy to forget that the Health Services also are under similar pressures, and the continuing support for the seminar programme by the Greater Glasgow Area Health Board is therefore particularly appreciated. Banking and travel facilities were provided by the Bank of Scotland and Mackays Travel Agency, to both of whom sincere thanks are due. Messrs John Dewar and Sons Limited, whisky Distillers, particularly favoured the occasion with a donation of their products for the benefit of participants at the conference banquet.

A seminar cannot be held on the scale of the present one without adequate publicity and the organisers are indebted to the Biological Engineering Society and the Hospital Physicists' Association for undertaking circulation of information and to the Biomedical Press UV and Taylor and Francis for publicity in their journals.

The organisers acknowledge again their sense of indebtedness to the City of Glasgow District Council for the warmth of the Civic Reception given by them to the seminar participants and guests.

Professor Kenedi, introducing the Adam Thomson Lecture, recalled the contribution to the growth of the Strathclyde Bioengineering Unit made by Emeritus Professor Adam Thomson. From his position as Head of Department of Mechanical Engineering at the Royal College of Science and Technology, which subsequently became the University of Strathclyde, he had been a wise counsellor and guide to many attending the seminar. His very considerable contribution to the University, and Bioengineering, has been gratefully acknowledged by the University's Court who established the Adam Thomson lectures in his honour. The attendance of Professor Thomson and Mrs Thomson was very much appreciated by all present.

Mr Perkins, Professor Kenedi recalled, has been associated with medical computing for many years and has long been an international leader in his field of study and research. His extensive participation and in particular his presentation of the Adam Thomson lecture contributed greatly to the potential for success of the seminar.

The undersigned wishes to warmly support Professor Kenedi's sentiments and also extends his thanks to Professor Kenedi for introducing the Adam Thomson lecture and more widely for his unflagging support of the Strathclyde Bioengineering Unit, and in particular the seminar series.

This is also the occasion to remember and thank all staff and students of the Bioengineering Unit for their help and forbearance. Similarly, thanks are due to the relevant administrative and supportive staff of the University for their support of the occasion. 
SEMINAR ORGANISING COMMITTEE AND SECRETARIAT

John P. Paul

Monica M. Jordan

Martin W. Ferguson-Pell

John D. S. Gaylor

Brian J. Andrews

Gail Bailey

Thomas R. M. Brown

Rita F. Cuthbert

John H. Evans

Corla M. van Griethuysen

Lorna B. Kerr

Linda Kneale

\}

Coordinators

Maria Lynch

Monica K. McColl

David J. MacDonald

Thelma M. Miller

Alexander C. Nicol

Clare Pinder

David A. Robb

Alexis M. Ross

David J. A. Smith

Elizabeth M. Smith

Alexander J. Tullis

Rosemary Wilkinson

Joan D. Wilson

John Maclean

\section{SESSION CHAIRMEN ASSOCIATES AND REPORTERS}

Brian J. Andrews

Martin W. Ferguson-Pell

John D. S. Gaylor

Monica M. Jordan

James MacGregor

Philip F. Millington

Sheila M. Nicol
Adrian Q. Beale

Stanley A. Floyd

Derek A. Hodson

Dennis F. Lovely

Sarah K. Marlow

Simon P. Marlow

Philippa J. McLeod

Graham Thynne 


\section{EXHIBITORS}

Barr and Stroud Ltd, Caxton Street, Glasgow, G13 1HZ, UK

Cardio Kinetics, 218 Regents Road, Salford, M2 3GS, UK

Delft University of Technology, Department of Electrical Engineering, Mekelweg 4, 2628 CD Delft, The Netherlands

Digital Equipment Co Ltd, Digital House, 252-256 Kings Road, Reading, RG1 4HS, UK

Fenwick Electronics, 301 Maxwell Road, Glasgow, G41 1TD, UK

Kontron Medical International, c/o Digital Electronics Ltd, 11 Greenhill Crescent, Holywell Industrial Estate, Watford, WD1 8XG, UK

Strathand Ltd, 44 St Andrews Square, Glasgow, G1 5PL, UK

Strathclyde Regional Council, Public Relations Department, India Street, Glasgow

Tandy Corporation, Tameway Tower, Bridge Street, Walsall, West Midlands, WS1 1 LA, UK

Universita Degli Studi Di Roma, Istituto Di Fisiologia Umana, Citta Universitaria, 00100 Roma, Italy

University of Glasgow, Department of Anaesthesia, Phase 1 Glasgow Royal Infirmary, Glasgow, G4 OSF, UK

University of Glasgow, Department of Electronics and Electrical Engineering, Glasgow, G12 8QQ, UK

University of Strathclyde, Bioengineering Unit, Wolfson Centre, 106 Rottenrow, Glasgow, G4 ONW, UK

University of Strathclyde, Department of Health Physics, John Anderson Building 107 Rottenrow, Glasgow, G4 ONG, UK

Versatec Electronics Ltd, 27-35 London Road, Newbury, Berkshire, RG13

$1 \mathrm{JL}, \mathrm{UK}$ 


\section{CONTENTS}

Preface v

Seminar Organising Committee, Secretariat, Chairman Associates and Reporters vii

Exhibitors viii

THE 1981 ADAM THOMSON LECTURE: TRANSFORMING DATA AND IDEAS INTO INFORMATION 1

W. J. Perkins, The National Institute for Medical Research, London 2

\section{SECTION A APPLICATIONS OF MICROPROCESSORS AND} MICROCOMPUTERS

1 Mini- and microcomputers in medical research M. M. Jordan

2 FRED: A microprocessor-controlled colour television display system for rehabilitation of the handicapped

D. J. Dewhurst

3 Microcomputer assisted cardiovascular monitoring

G. N. C. Kenny and D. Campbell

4 MICKIE: Experiences of interviewing patients by micro

S. S. Somerville, J. S. Stewart and G. E. T. Raine

5 Interactive computing in the microbiology laboratory

F. Johnson, N. Pearson, T. McDonald and F. W. O'Grady

6 Data processing in pathology laboratories: why has it taken so long to come of age?

N. W. Carter

7 A laboratory microcomputing system for physiological signal and system analysis

S. R. Smith, L. Jankovic, T. Going and S. Lal

8 On-line analysis of respiratory waveform with a microcomputer

P. D. Davis, G. N. C. Kenny and D. Campbell

9 A portable microprocessor-based heart-rate meter

C. J. Watkins and J. R. Roberts

10 ECG data compression: some practical considerations

J. C. M. Peden

11 An analysis of heart-rate variability after myocardial infarction

S. R. W. Grainger, S. R. Rakowski and P. C. Carson 
12 Patient monitoring by computer-large or small?

J. S. S. Stewart

Section A Discussion

SECTION B PANEL DISCUSSION 1

1 Patterns in signals

J. H. van Bemmel

2 Progress with CARE

P. W. MacFarlane, A. Irving, J. C. M. Peden, M. Podolski, D. Shoat, M. P. Watts and T. D. V. Lawrie

3 On-line information and data reduction in patient monitoring

J. A. Blom and J. E. W. Beneken

4 Modelling respiratory sinus arrhythmia and its application to the study of neuropathy

R. I. Kitney

5 An automatic system for clinical gait analysis

A. Cappozzo, F. Di Giacinto, T. Leo and V. Macellari

6 The Strathclyde TV system for human motion analysis

B. J. Andrews, S. M. Nicol, G. Thynne and A. Q. Beale

7 A quantitative method for assessment of differentiation techniques used for locomotion analysis

B. J. Andrews, A. Cappozzo and F. Gazzani

8 A computer assisted quantitative description of human muscle contraction tension-time relationship

K. Larsen, N. H. Secher and N. Rube

9 On-line analysis of motor unit action potentials and the interpretation of specific parameters

K. L. Boon and A. R. Th. Pelsmaeker

10 An averaging technique for a rowing exercise ECG test

J. A. van Alsté and W. van Eck

Section D Discussion

1 Digital image processing in medicine

R. S. Ledley, L. S. Rotolo and T. J. Golab

2 Interactive pattern recognition; desirability and characteristics of a system

E. S. Gelsema 
3 Interactive raster graphics for CT scans

J. A. Newell and E. Sokolowska

4 Signal processing and analysis of biological images

A. N. Barrett

5 Chromosome analysis: image processing or pattern recognition?

J. R. I. Piper

6 Graphic system for angiographic and echographic images processing and display

J. F. Lerallut, G. Fontenier and M. Y. Jaffrin

7 Research in medical image perception; a microprocessor application

A. G. Gale, F. Johnson and B. S. Worthington

8 Statistical extraction of features from high-dimensional processes

R. Hanka

9 Estimation and precision of 3-D kinematics by analytical photogrammetry

H. J. Woltring

10 Syntatic pattern analysis of 24-hour Holter records

I. C. Jenkins, S. A. Briller and P. J. Ollapally

Section E Discussion

\section{SECTION F INFORMATION PROCESSING}

1 Cohort studies and calculating risk

V. M. Hawthorne

2 The development of a diagnostic decision system

W. I. Card, G. P. Crean, R. P. Knill-Jones, R. W. Lucas and

D. Spiegelhalter

3 Integrated health computing: a practical philosophy in

Western Scotland

J. S. Bryden, D. Davidson, J. Dow and A. Lamont

4 The use of mainframe computers and Scottish Health Service Statistics

M. A. Heasman

5 A comparison of the structures of computing systems and hospital systems - past, present and future

D. Millington

6 The use of microcomputers in medical education

C. Schmulian and G. N. C. Kenny

7 An evaluation of a clinically oriented district-based maternity records system

R. C. L. Howat, P. Stewart and S. M. Nicol

8 The nurse to computer interface

J. S. Bailey, R. Wyatt and J. M. Allwood

9 The measurement and description of the surface texture of the skin

J. C. Barbenel, S. Makki and P. Agache 
10 Real time computer calculation of heart rate and its variability in the human fetus using an 'indirect' or transabdominal ECG signal K. J. Dalton

11 A microprocessor-based colonic motility index monitor G. Winstanley, S. R. Rakowski and C. H. J. Swan

12 Foresight and hindsight in the storage of clinical records D. A. McGrouther

Section F Discussion

1 Computer modelling in physiology and medicine

C. J. Dickinson

2 System identification and parameter estimation techniques in the modelling of physiological systems: a review

D. J. Murray-Smith

3 A structural approach to respiratory control simulation

W. Greer, M. M. Jordan and D. J. Murray-Smith

4 A dynamic model of the respiratory system

W. Fincham and F. T. Tehrani

5 Mathematical modelling of bilirubin removal from jaundiced newborn babies by haemoperfusion

L. S. Fishler, S. Sideman, L. Mor and J. M. Brandes

6 Modelling of peritoneal dialysis

L. C. Smeby and T.-E. Wider $\phi$ e

7 Modelling human postural control

Z. J. Koles

Section G Discussion 